\title{
清酒おけ物取引の現状と 当面の対策について
}

清酒業界にあっては, おけ物取引に媒介されて, 上位大規模メーカー

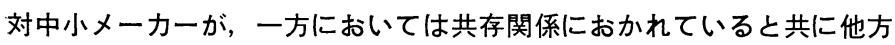
では低成長経済の進展につれて買い手側である大規模メーカーの優位は 強化されつつある。

問題の根本的解決の方向は, おけ売の依存度が高い中小清酒メーカー がおけ売から脱却して独自の市場を回復または創造する可能性を探険す ることにあると思われるが，それには何程かの準備期間を必要とする。 そこで, さし当っては, おけ物取引が摩擦と混乱を出来得る限り避ける ことによって安定的に推移することが望ましい。本論文は, おけ物取引 の現状分析に立脚して傾聴に值する方策が提案されている。

前国税庁酒税課課長補佐

谷安司

清酒のおけ物取引は, 原料米割当制度や生産数量カル テルが実施されていた当時は, 特に生産性の低い階層を 除いては, 中小の業者であっても再生産の可能な価格で 取引が行われ，扮打む䄈安定的に推移してきたところで ある。しかし, 生産の自由化を迎えた $49 \mathrm{~B} \mathrm{Y} \mathrm{からは,}$ 樣相を一变することとなった。すなわち，48 B Y の清酒 生産は史上はじめて 1,000 万石を越えという大增産が行 われたが，49 年は我が国経済全体が石油ショックに伴 深刻な不況に見舞われ, 清酒の需要は停滞し, 課税移 出数量は対前 B Y 比 $4 \%$ （F Y 対比では 10\%)の減少と なって供給過剩がにわかに表面化してきた。

このような需給のアンバランスを背景として，牧け物 取引は買手に一層有利に展開して, 出け物価格は相対的 飞低下し, 和活売企業の大半がコスト 割れを余儀なくされる事態となってい る。しかも, 業界の相当多数の者が拉 け物取引に大きく依存していることか ら,この打物取引の安定は, 清酒業 界とりわけ中小㧤茪企業にとって, 当面する切実な課題となっているとこ ろである。清酒業界は今日, 年々上昇 する原料米問題をはじめ, 酒類間競争 の問題その他多くの解決のむつかしい 難題をかかえているところであるが, 本稿では, おけ物取引の問題に焦点を
しぼって，その現状と今後の見通し，また，当面するお け物取引安定の課題についていくつかの提言を試み, 識 者のご批判をあおぐこととしたい。

な呿, 当然のことながら, 本稿の意見にわたる部分は 筆者の個人的な見解であることをはじめに抗ことわりし て扰きたい。

\section{1 おけ物取引の現状}

\section{（1）取引数量等の実情}

44 年度から 50 年度までの括け物取引の状況は, 資料 1 「最近に打以る清酒の拈け取引状況」のとおり，50 年 度でみると，扮け売製造場は全製造場の $72.5 \%$ にあた る 2,348 場に達し, 未納税取引される数量は, 清酒の全

資料 1 最近飞括ける清酒の拈け取引状況

\begin{tabular}{|c|c|c|c|c|c|c|c|c|c|c|c|}
\hline \multirow[b]{2}{*}{ 年 度 } & \multicolumn{2}{|c|}{ 全製造場 } & \multicolumn{3}{|c|}{ 特け売り製造埸 } & \multicolumn{3}{|c|}{ 制 令 } & \multicolumn{3}{|c|}{ 製成数量対虍け売り } \\
\hline & \begin{tabular}{|l} 
場 \\
(数) \\
(場)
\end{tabular} & 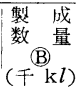 & $\begin{array}{l}\text { 場 } \\
\text { ( 数 } \\
\text { (勎) }\end{array}$ & 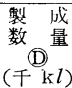 & 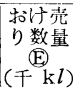 & $\begin{array}{l}\text { (C)/A } \\
(\%)\end{array}$ & $\begin{array}{l}(\mathrm{E}) /(\mathrm{B}) \\
(\%)\end{array}$ & $\begin{array}{l}\text { (E) } / \mathbb{D} \\
(\%)\end{array}$ & $\begin{array}{c}80 \% \\
\text { 以 } 5 \\
\text { (場) }\end{array}$ & $\begin{array}{c}60 \sim \\
80 \% \\
(\text { 場) }\end{array}$ & \begin{tabular}{|c|}
$60 \%$ \\
未满 \\
(场)
\end{tabular} \\
\hline 44 & 3, 748 & 1,166 & 3,027 & 792 & 391 & 80.0 & 33. & 49.4 & 905 & 594 & 1,528 \\
\hline 45 & 3,643 & 1,258 & 2,994 & 88 & 432 & 82.2 & 34.3 & 48. & 718 & 65 & 1,611 \\
\hline 46 & 3,470 & 1,330 & 2,829 & 918 & 418 & 81.5 & 31.4 & 45.5 & 579 & 35 & 1,615 \\
\hline 47 & 3,397 & 1,361 & 2,695 & 954 & 501 & 79.3 & 36.8 & 52.5 & 672 & 99 & 1,213 \\
\hline 48 & 3,351 & 1,422 & 2,576 & 957 & 518 & 76.9 & 36.4 & 54.1 & 578 & 543 & 1,193 \\
\hline 49 & 3,285 & 1,422 & 2,454 & 904 & 493 & 74.7 & 34.7 & 54.5 & 537 & 565 & 1,144 \\
\hline 50 & 3,238 & 1,364 & 2,348 & 879 & 524 & 72.5 & 38.4 & 59.6 & 727 & 468 & 979 \\
\hline
\end{tabular}

（注） 1.この表の製造場には，其同びん萂場を含む。

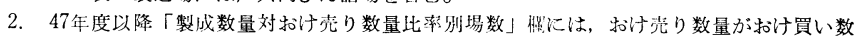

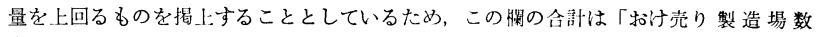
(C)」符合しない。 
製成数量（原仾 $20 \%$ ）の $38.4 \%$ ，打け売のある製造場 で製成された清酒の $59.6 \%$ を占めている。このうち, 扣け売比率が $80 \%$ 以上の製造場は 727 場， $80 \%$ 未満 $60 \%$ 以上の製造場は 468 場となっており，60\% 以上お け売している製造場は 1,195 場に及んでいる。時系列で みると，颃け売製造場の割合は，45 年度の $82.2 \%$ をピ 一クに次第に減少して 50 年度には $72.5 \%$ となってい る反面，おけ売数量の割合は $30 \%$ 台の横這いであるが おけ売のある製造場のおけ売比率は，46 年度の $45.5 \%$ を底として次第に増加し，50 年度は $59.6 \%$ となって㧊 り，拉け売の淘汰選別と専業化の進行を示している。ま た，おけ壳型企業（製成数量の $50 \%$ 以上を护売して いる者）を規模別にみると，資料 2 「括け売型企業の製 成数量規模別業者数等」のとおり

$\begin{array}{lc}\text { 製成数量規模 } 100 \mathrm{k} l \text { 以下 } & 7.7 \% \\ 100 \mathrm{k} l \sim 200 \mathrm{k} l \text { 未満 } & 43.6 \\ 200 \mathrm{k} l \sim 300 \mathrm{k} l \text { " } & 18.7 \\ 300 \mathrm{k} l \sim 500 \mathrm{k} l \text { " } & 14.5 \\ 500 \mathrm{k} l \sim 1,000 \mathrm{k} l \text { " } & 9.6 \\ 1,000 \mathrm{k} l \sim 5,000 \mathrm{k} l " \prime & 5.7 \\ 5,000 \mathrm{k} l \text { 超 } & 0.2 \\ \text { 合 計 } & 1,362 \text { 者 } 100.0 \%\end{array}$

であり，その大部分が製成規模 $1,000 \mathrm{k} l$ 末澫（1,282 者 $94.1 \%$ ）の中小業者で，特に $200 \mathrm{k} l$ 未満の階層が $50 \%$ を超えているところに特色がある。

お㤝型企業と対照的な姿となっているのが，おけ買 企業側で，資料 3 「おけ買企業の上位集中度」のと㧍

資料 2 おけ壳型企業の製成数量規模別業者数等 （アルコール分 20 度）

\begin{tabular}{|c|c|c|c|c|}
\hline 区 分 & & & & \\
\hline $\begin{array}{l}\text { 製成数量 } \\
\text { 規模 }(\mathrm{k} l)\end{array}$ & 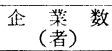 & 集 $\begin{array}{c}\text { 中 } \\
(\%)\end{array}$ & 企 $\begin{array}{c}\text { 業 } \\
\text { (数) }\end{array}$ & $\begin{array}{c}\text { 集 } \\
(\%)\end{array}$ \\
\hline 100 以 下 & 92 & 6.9 & 105 & 7.7 \\
\hline $100 \sim 200$ & 590 & 44.0 & 594 & 43.6 \\
\hline $200 \sim 300$ & 258 & 19.3 & 255 & 18.7 \\
\hline $300 \sim 500$ & 206 & 15.4 & 197 & 14.5 \\
\hline $500 \sim 1,000$ & 123 & 9.2 & 131 & 9.6 \\
\hline $1,000 \sim 2,000$ & 54 & 4.0 & 55 & 4.1 \\
\hline $2,000 \sim 5,000$ & 13 & 1.0 & 22 & 1.6 \\
\hline 5,000 超 & 3 & 0.2 & 3 & 0.2 \\
\hline 計 (将均) & 1,339 & 100.0 & 1,362 & 100.0 \\
\hline
\end{tabular}

（注）この表は, 清酒製造栄者火態調查によるるのである。

資料 3 打け買企業の上位集中度（昭和 50 年度）

\begin{tabular}{|c|c|c|c|}
\hline $\begin{array}{ll}\text { 分 } \\
\text { 課税移出 } \\
\text { 数量規模 }\end{array}$ & 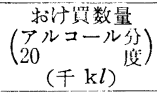 & 集 $\underset{(\%)}{\text { 中 }}$ & $\begin{array}{c}\text { 打计買制合 } \\
(\%)\end{array}$ \\
\hline 上位 10 者到 & 326 & 61.4 & 65.4 \\
\hline " 20 者計 & 403 & 76.0 & 63.4 \\
\hline " 50 者計 & 448 & 84.4 & 57.3 \\
\hline "/ 100 者計 & 474 & 89.2 & 51.6 \\
\hline 壾 & 531 & 100.0 & \\
\hline
\end{tabular}

第 72 巻 第 8 号
り, 課税移出数量規模で上位 10 社が全おけ取引数量の 約 60\%を打け買いしており，課税移出数量規模で上位 100 社までをとると，おけ取引数量の約 9 割を占めてい る。また，課税移出規模の上位の社は打け買依存度（課 税移出数量に占める打賣酒の比率）女高く, 課税移出 規模上位 10 社の平均は $65.4 \%$, 上位 100 社平均でも $51.6 \%$ に達している。

このよらに課税移出規模の上位の社に打け買数量が集 中し，また，おけ買酒への依存度が高いことは，お賏 大手の動向がおけ物問題解決の鍵を握っていることを示 しているといえよう。

\section{（2）おけ物取引の歴史的経緯}

おケ物取引は，戦前においても仲間取引として存在し ていたが，それは現在のおけ物取引とはかなり異質のも のであった。また，戦中戦後にかけて清酒の生産がきび しく制限されていた当時は，清酒の絶対量が不足してお り，流通段階では厳しい配給制度がとられていたため， おけ物取引の発生する余地はなかった。

それが，大々的に行われるようになったのは，昭和 30 年代以降のことである。原料米の割当制度の下にあって 販売力を有する大手業者は，自製酒のみでは販壳量を満 たし得ない状況が生じ，他方，一般の中小業者は，自製 酒に余裕がある状況とともに割当制度の下では清酒の需 給の均衡がとれていたことから，拈け売によっても一定 の収益を挙げることができたため，おけ物取引は次第に 増加することとなった（資料４「拉け売製造場及びおけ 壳数量の構成比推移表」参照)。

今日の拈物取引を制度的に支えてきたのは，清酒の 製造免許制度と原料米割当制度であったが，昭和 44 年 の自主流通米制度への移行は中小おけ売企業の経営を根 底からゆさぶるものであった。経過的に生産カルテルが 採られたところであるが，清酒の需給関係は逆転してお け物取引は買手市場となり，このため，おけ物取引を通 じて収益を挙げることは次第に困難となって今日に及ん でいる。

特に問題があるのは, 小規模なおけ㧤企業であって,

資料 4 打け売製造場及び和け売数量の 構成比推移袁

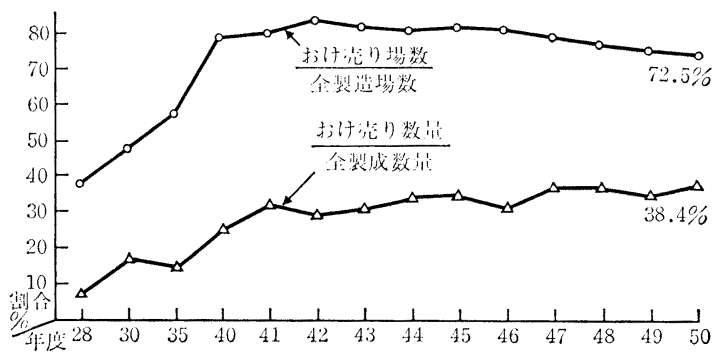


資料 5 打け売企業数等の推移

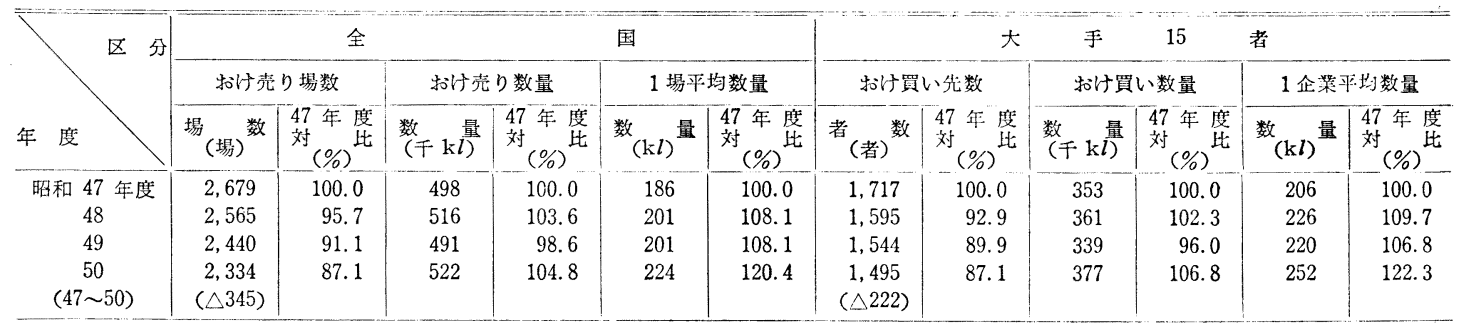

（注）共同びん詰場とその構成員間の未納税移出入は除いている。

コスト面からみて今後打け売業者として存続すること は，きわめて困難な見通しである。

\section{（3）現状における問題点}

以上見てきたよらに，晾物取引が少なくとも再生産 可能な価格で行われ，当分の間安定的に維持される見通 しがあれば，社会的分業としておけ物取引は業界の中に 一応定着していると見ることができる。しかし，打け物 取引をめぐる今日の環境条件はきわめてきびしく，拈け 価格の低迷とともに取引先選別の不安が扣け売企業全体 を覆っているところである。

その第 1 は，おけ価格のコスト割れの現実である。 40 年代を通じて清酒市場は買手に有利に推移してきたが， おけ物取引の面では一層買手市場の様相を呈している。 特に, 48 年秋の石油ショック以降はその度合を強め, おけ売価格は相対的に低下して，その大部分がコスト割 れの実態を示している。すなわち，清酒製造業の実態調 査によれば，打け売型企業の製成階層別製造コストと括 け買大手の平均引取価格の対比では 47 事業年度には $100 \mathrm{k} l$ 以下の階層のみがコスト割れであったのが，49事 業年度には $300 \mathrm{k} l$ 以下の階層がコスト割れとなり，50事 業年度にいたっては $1,000 \mathrm{k} l$ 以下の階尿がコスト割れと なっている。先にも示したように括け売型企業で製成規 模が $1,000 \mathrm{k} l$ を超える者は全体の $5.2 \%$ を占めるに過ぎ ないところから，今日の拈け価格の水準では大多数の企 業が再生産不可能の状態に追い込まれていることは統計 上明らかであり，和け取引について抜本的な対策を望む 声が高まっているのも肯定できるところである。

その第 2 は, お諏引先選別の進行である。大手 15 社のおけ買先企業数の推移をみると，47F Yを100 とし て 48F Y 92.9, 49 F Y 89.9, 50 F Y 87.1 と連年減少 して拈り，今後に拈いてもこの傾向はな打当分の間は続 くものと予想される（資料 5 「おけ売企業数等の推移」 参照)。すなわち, 大手の括け物取引についての考方方 を要約すると拈执むね次のと拈りである。

当面は, 稼動率を高め, 自製酒比率を高める。

口しかし, 清酒の需要が今後大きな伸びを期待でき ないと予想されることから，扣け買酒表示問題が今
後一㐿発展しない限りは, 大規模な設備投資を避故 て，おけ買によって需給の調整を図る。

したがって，括け置数量は比率としては低下する が，絶対盐では大手のシェアー抎大が続くならば, 増加することが予想される。

、括け買先については, 立地, 規模, 品質, 価格な ぞ買い侧にとって経済的メリットの大きな業者ない しは人的, 資金的につながりの強い業者にしぼり, その他の業者は次第に選別していくものと考えられ る。

おけ買企業側の括け物取引についての基本的なビへ一 ビヤーは以上のと拈りであって，このことから遠隔地あ るいは小規模の打浣企業は, 打売からの撤退をいず れ余儀なくされるものと思われる。

第 3 の問題点は，業界全体としてみた場合に清酒の需 要に較らべ過大な設備を保有していることである。

過大な生産能力を有していることが, 第 1 , 第 2 に指 摘した問題点の背景となっていることを䓅えれば,より 基本的に重要な問題点ともいえよう。

最新の実態調查によれば, 50 事業年度末の全体とし ての生産能力は, 約 185 万 $\mathrm{k} l$ (原酒 $20 \%$ 換算) に達し ているが, 需要に見合った清酒の生産量は 140 万 $\mathrm{k} l$ 程 度と考えられる。仮に若干の余裕をみて稼動率 $85 \%$ と しても 165 万 $\mathrm{k} l(140 \times 100 / 85=164.7)$ 程度の設備で十 分であり, 約 20 万 $\mathrm{k} l$ の生産能力が全体として過唾であ るということができる。

清酒業界にとって不幸であったことは，第 2 次の近代 化によって設備投資が行われたにもかかわらず，清酒の 需要は予想に反して全体として停滞し，今後においても さして需要增を期待できない状況となり，折角の新鋭設 備をフル稼動できないばかりか, 増加した設備が常に過 剩生産の危険をもたらしていることである。

すなわわ, 新設工場にあっては多くの場合, フル稼動 によってようやく減価償却と金利負担をカバーできる計 算となっていることから, 企業採算上既存の企業以上に 増産志向が強く, 余䛢に生産された清酒が括け物市場へ 流入して，拈け物価格の低迷に拍本をかける原因の一つ 
となっているとの見方もあながら否定できないところで ある。

\section{2. 当面の対応策について}

以上のと括り，自由化を前提にすればおけ物取引が今 後も現状のままで継続することは，まずあり得ないと考 えるべきであり，日本酒造組合中央会の中小企業対象委 員会でる，「特け取引制度が，現状のままで将来長く続 けられる可能性は，まず考兄られないとするならば，基 本的には打け取引から撤退をしなければならないことに なろら」とし，「将来の転進の方向を探る」必要性を認 めている（日本酒造組合中央会中小企業対策委員会報告 「小企業対策を中心とした業界の中期対策」p.76 参 照)。

自由主義経済は, 自由な競争を通じて自然淘汰が行わ れ, 資源や資本の再配置が図られ, 産業の発展が期せら れるとするものであることからすると，何らの対策もと らず，自然の推移に季かすことが最良の施策であるとの 考え方もあるところである。

しかし, 清酒の需要が停滞している一方で過剩設備を かか觉ている現状のまま，競争原理のみにゆだねる場合 には, 自然淘汰が急激に起こり, 清酒業界の混乱にとど まらず, 卸, 小売業界へす過渡的には重大な影響を与兄 る怙それがあり，それを放置することには，今日の社会 情勢からみても問題のあるところであろう。

中央酒類審議会の「中間とりまとめ」においても, 拧 村物取引について,「既存設借の有效活用といら経済合 理性も認められ, また, 業界構造の激変を避ける必要も あるところから, 当面, 行政的には, 抬け買企業に節度 を求め, 選別化伴摩擦を少なくするよう求めること が必要であ万う」とし，具体的な施策として，

(1) 注文生産に括ける価格決定の合理化, 契約期間の 安定を図ること

(2) 批買企業を中心とする批売企業の合同化，協 業化を推進すること

等を提案しているところである。

確かに，括壮物取引の展望はきびしいるのがあり，平 均的に久て生産性の低い小規模な打湑型企業が将来に わたって「括计」に依存することはきわめて難しいと言 わざるを得ないが，上記の中央酒類審議会の意見を参考 としつつ, 現行特计物取引の改善策として教兄られる施 策を述べることとしたい。

\section{（1）注文生産制度の改善}

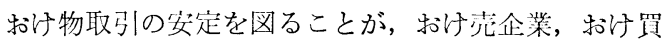
企業双方にとって好ましいとの認識に立って, 括讨物取 引についての注文生産制度が 48 年 10 月より発足してい
る。

この制度の骨子は

1 毎年 10 月末日までにおけ買企業は個々の和け取 引数量等を決定して契約を行う。

口 契約を締結した以外の清酒については, 原則的に は未納税和け取引を認めない。

とするもので, この制度の概要を図示すると次のとおり である。

注文生産制度の概要困

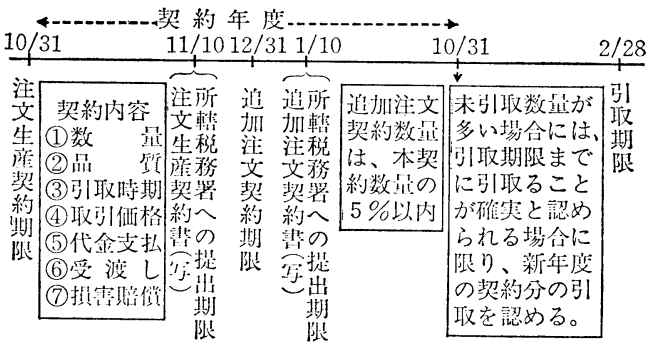

現行の注文生産制度は, 確かに, いわゆる「みずてん おけ」を追放し，括け売側の過大な生産を抑制する上で 一定の効果をあげているし，また，打け買酒表示問題に ついても，消費者に一応の説明ができる制度であること 等十分に評価できる面を持っている。しかし，京将売側 にとって最大の関心事である価格の安定については，か ならずしも予期したほどの効果をあげていない実情であ る。現行の「未納税打け取引に打ける注文生産制要綱」 （中央会制定）では，お物価格について，「注文生産制 取引にかかる清酒の価格は，打㤝常者の一般的製造原 価々の他を考慮して双方協議の上，合理的に決める。な お，おけ取引の継続的安定のため，この価格は，おけ売 企業が再生産をなし得るに足るるのでなければならな い」と定め,「括け取引契約書」の例示では, 取引価格 につき，「本契約による引取清酒の価格は，別にこれを 定める」とし，「おけ取引単価契約書」の例示では，引 取期限ごとに金額を明示すことになっている。

しかし，現実の取引に当っては，当初に単価を定める 例は少なく，暫定価格何円とするにとどまり，製品の引 渡し時, または後日に若干の手直しをするのが一般であ る。そして，こうして決定された取引価格は，ここ数年 来, 生産が全体として過剩気味で，おけ取引はおけ買側 が圧倒的に強い立場にあること等から，製造原価すれす れまたは製造原価を㓶るような低い価格となっている。 そらして，拈け売側は価格に不満があっても次の契約に 影響があってはとの思惑から，括愪側の申出に従らほ かはないのが実情である。先に，拈け価格が相対的に低 下していることに触れたが，50 B Y 生産清酒の括泟格 の水準では, 打け売型企業のうち, $1,000 \mathrm{k} l$ 以下の階層 
が平均的にはコスト割れとなっており，おけ買大手企業 の平均的な製造原価さえも下回っていると推定される。 「おけ買酒は自製酒より高い」との主張を時として聞く が，その場合の自製酒原価は直接の製造費用のみであっ て，当然に加算されるべき管理費や製造から製品として びん詰されるまでの貯藏期間に対応する金利が含まれて いない場合が多い。必らずしも厳密な計算ではないが, 積み重対られた実態調査の分析によると，47 事業年度 までは買い入れ酒の方が自製酒より高い実態であったの が，49 事業年度には逆転し，50 事業年度にはそれが一 層拡大していることが，平均的な傾向値として伺われ る。確かに, 製造原価は規模の拡大とともに聥減するが (資料 6 「打け売企業の製成規模別原価と打け価格の比 較表」参照)，新規の設備による場合は莫大な資金を要 し，その金利と減価償却が大きく，製造コストとしては 既存工場の方が有利と認められる（資料７「新設工場の 製造コスト試算表」参照)。

大手企業の平均的な操業度は, 括け売型企業の平均的 な操業度より低いことから製造原価が高く計算される面 はあるが，仮りに操業度を 100\%に高めても，な拉，過 半数を拝㵋酒に依存しなければならないことも事実で ある。怙け買に今後とも長期にわたって依存せざるを得 ない生産構造にある以上は, 売り側の過当競争につけ込 むような行き方には節度が求められてもよいのではなか ろらか。「双方協議の上, 合理的に決める」べきものが, 運用の実際面でおけ買側の意向に強く左右される傾向が あるとすれば，合理的な決定ができる制度の導入や算定 方法の改善が図られてしかるべきであろら。

注文生産制度の本旨にかえり, 標準的な規格のお物 について, 公正かつ妥当な価格形成がなされるよう適当

資料 6 打壮売企業の製成規模別原価と括け価格の 比較表 (49 事業年度) アルコール分 20 度 専業割合

\section{$1.8 l$ 当り} $90 \%$ 以上

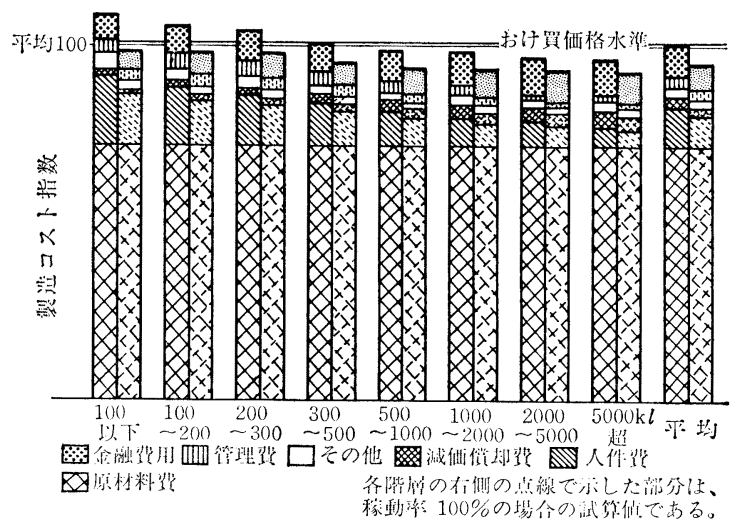

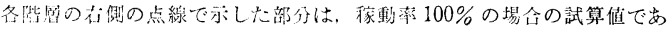
る。
な委員会の設置と, その委員会による合理的な算定方式 の確立を提案したい。幸い, 清酒製造業の実態調查が連 年実施されており, 標準的な酒質の清酒を造る場合の原 単位あたりの平均的な原材料, 労働力, その他の諸経費 等について必要な基礎資料はかなり整っているところで あり, 打け買側の理解と協力があれば, 合理的な算定方 式を求めることは可能である。そうして各企業は, これ を参考として個々の酒質の清酒について具体的な取引価 格を定めることとする慣行を確立することはどうである らか。

勿論このことは, 資料 6 亿もみられると㧍り, 生産性 の低い階層までカバーされるような価格が期待される訳 では決してない。低きに失している現在のおけ物価格を 合理的な水準にまで回復しょうとするものであって, 低 い生産性の企業にあっては, 集約等によって生産性を高

資料 7 新設工場の製造コスト試算表 (49 B Y, 稼動率 $85 \%$, アルコール分 20 度, 1. $8 l$ 当り)

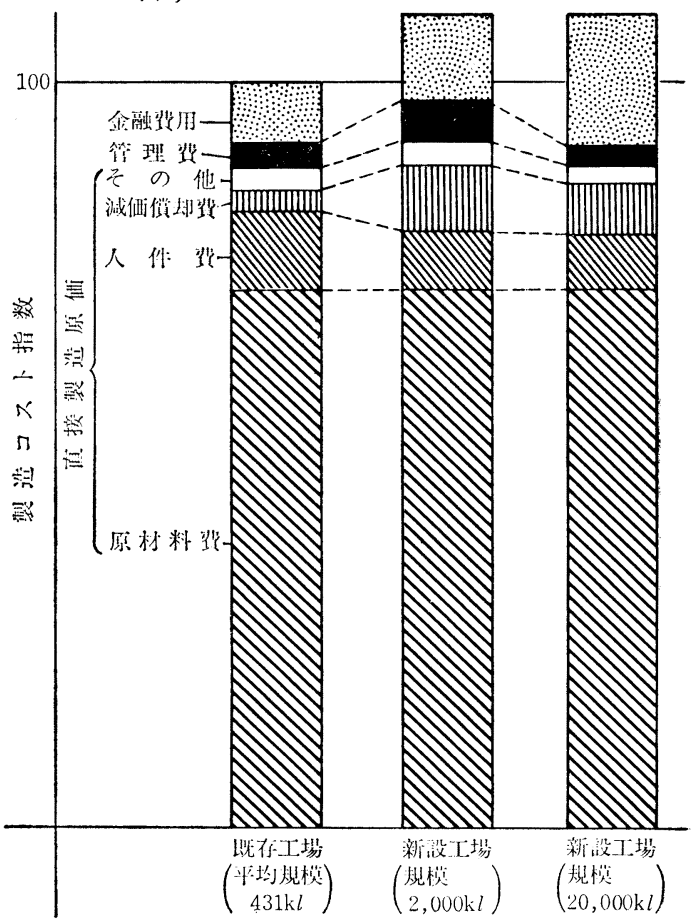

（注） 1. 既存工埸（年間平均製造规標 $431 \mathrm{k} l$ ) 49 事策年度の扰芜型企業の诗埴によった。

2. 新設工場

（1）年間製造规模 $2,000 \mathrm{k} l$ の工場

\begin{tabular}{|c|c|}
\hline 設储投資額 & 451 \\
\hline 常度化資金 & 293 \\
\hline ウ小公庫 & 158 \\
\hline
\end{tabular}

（2）年間製造规模 $20,000 \mathrm{k} l$ の工場 設储投凟额 3,998 实万円

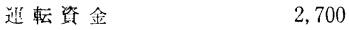

3. 新設工場の瑊佂償却費は定额法によった。 
めて「批」としてとどまるか，転進の途をさぐるかの 選択が必要なことは止むを得ないことであろう。

\section{（2） 契約期間について}

現在の注文生産制度に打ける契約期間は単年度となっ ているため，打け売企業の多くは次年度以降の取引につ いて不安を抱いているだけでなく，1年先が判らないこ とから, 経営計画はもとより, タンク取替えのような小 規模の設備投資計画すらたてられない実情にあるといわ れている。和け取引を安定させるためには, 契約期間の 安定を図ることが必要であるが，注文生産制度の運用の 上で現行の単年度契約を, 例えば一率 3 年以上とするよ らな取扱いに改めることについては，業界のコンセンサ スが得られるかどらか疑問であり，また，選別を促進さ せる結果ともなりかねない面がある。拈け買大手におい ても良質の怙けを供給する相手先との取引は今後とも継 続する意向を有しているところであるから，一率の長期 化は避け, むしろ, やむを得ず取引先を選別する場合に は，打け売企業がこれに対応できるよう，例えば，取引 を行わないこととなる前々酒造年度末すでに取引停止の 予告をする慣行を導入することを検討してはどらである らか。

\section{（3）おけ売企業の集約化等の促進}

資料 6 によっても明らかなように, 製造原価は規模の 大きさにほぼ正比例して低下するとともに，稼動率によ って大きく影響をらけることが同える。

また，大型の設備投资をするよりも既存設備の方がコ スト面で優位にあることから，集約化によって既存設備 のフル稼動ができれば，コストを相当程度引下げること が可能であり，打売批買双方にとってプラスである
ことも明らかなところである。大手企業のなかには，系 列の淤け売企業に対して積極的に資本参加してその統 合, 合併を図り, 品質を維持しつつ製造コストの引下げ に成功している事例もある。このよらな事例を参考に, 一定の資本参加や資金助成, 技術指導等が行われ，扣け 買企業との結び付きが強化される場合には，そこで製成 され, 親企業に供給される清酒については自製酒と同等 の取扱いをする等の誘導政策が行われるならば, くすぶ っている自製酒比率問題への解決ともなり，打忊買主導 による集約化, 再編成が促進されることとならないだる らか。

\section{結びにかえて}

当面の猢物取引の安定策について述べてきたが，お け物取引の安定ひいては清酒業界の安定には, 需要に較 べて過大な生産設備の解消を図ることが，より抜本的な 対策であるとの意見も少なくない。中央酒類審議会の 「中間とりまとめ」でも,「 3 千の業者がすべて今後存続 すると期待することは困難であり，また，すべて現状を 温存するような行政は, 国民経済的にも批判を免れない であろう」ととりまとめているところである。有力企業 のなかにも, 業界のコンセンサスが得られるならば, 生 産性の低い生産設備の解消には協力を惜しまないとの声 もきかれる。この問題は清酒業にかぎらず, 成熟した産 業に共通した悩みであり，また，くぐり拔けなければな らない難関でもある。衆知を集め論議をつくして抜本策 を樹てられることを期待し, 当面の拈け取引の安定策に ついての愚稿を結ぶこととしたい。

（新東京国際空港公団勤務） 